International Journal of Life Sciences
Available online at http://sciencescholar.us/journal/index.php/ijls
Vol. 2 No. 2, August 2018, pages: $12 \sim 21$
e-ISSN: 2550-6986, p-ISSN: 2550-6994
http://dx.doi.org/10.29332/ijls.v2n2.119

\title{
Gelatin Characteristics of Bali Cattle Skin Protein Extract on Acetic Acid Concentration and Different Length of Curing
}

\author{
I Nyoman Sumerta Miwada a, I Ketut Sumadi b , Luh Putu Wrasiati c, I Nyoman Sutarpa Sutama ${ }^{\text {d }}$ \\ Article history: Received 10 December 2017, Accepted in revised form 20 March 2018, Approved 30 April 2018, \\ Available online 7 May 2018
}

\section{Correspondence Author a}

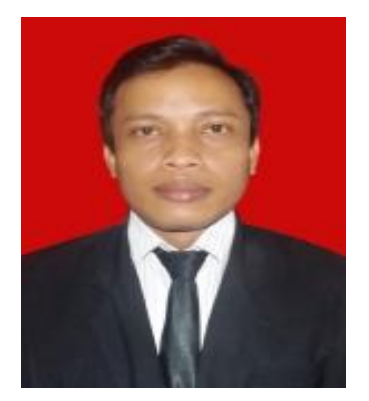

Keywords

Animal skin;

Bali cattle skin;

Extract;

Gelatin characteristic;

Gelatin production;

\begin{abstract}
Gelatin Production of Bali cattle skin protein extract is an alternative to obtain permitted gelatin. The objective of the research was to know the effect of concentration and different acetic acid curing time to gelatin characteristic of the animal skin and to determine the best of the characteristic. Indicators of them were $\mathrm{pH}$ value, the yield of gelatin, moisture content, protein, fat, viscosity and gel strength. The extraction of Bali cattle skin protein was conducted with curing for 2; 4; and 6 days and acetic acid on concentration 2\%; 4\%; 6\% and 8\%. Statistical analyzed showed that increased of acetic acid concentration and curing time and its interaction was significant $(\mathrm{P}<0.05)$ affected the quality of the animal skin gelatin. Index of effectiveness showed that the best treatments combination was on acetic acid concentration $8 \%$ and curing time 6 days (A4C3) in produced gelatin. Indicator of quality were yield of gelatin $(11.91 \%)$; water concentration (10\%); protein $(88.13 \%)$; fat $(0.98 \%)$ and viscosity $(5.35 \mathrm{cP})$. It can be concluded that the increase of acetic acid concentration and curing time affected quantity and quality of the animal skin gelatin.
\end{abstract}

e-ISSN : 2550-6986, p-ISSN : 2550-6994@ Copyright 2018. The Author. SS Journals Published by Universidad Técnica de Manabí. This is an open-access article under the CC BY-SA 4.0 license (https://creativecommons.org/licenses/by-sa/4.0/) All rights reserved.

\section{Contents}

Abstract

1. Introduction

2. Research Method 13

3. Results and Analysis 14

3.1 Value of gelatin $\mathrm{pH}$.

a Student of Doctoral Program of Animal Science Faculty, Udayana University, Bukit Jimbaran Badung, Bali-Indonesia

b Faculty of Animal Science, Udayana University, Bukit Jimbaran Badung, Bali-Indonesia

c Faculty of Agricultural Technology, Udayana University, Bukit Jimbaran Badung, Bali-Indonesia

d Faculty of Animal Science, Udayana University, Bukit Jimbaran Badung, Bali-Indonesia 


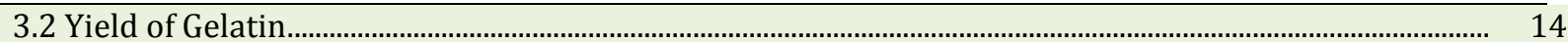

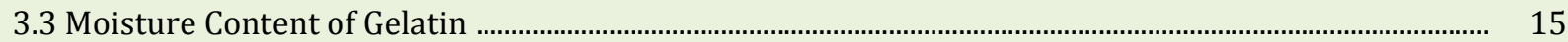

3.4 Protein Content of Gelatin ........................................................................................................................................ 15

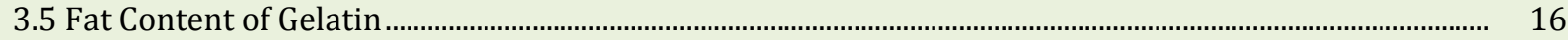

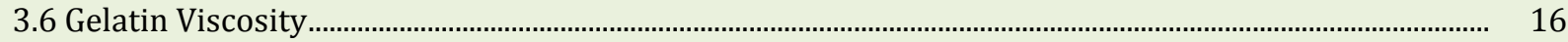

3.7 Gelatin Gel Strength................................................................................................................................................ 17

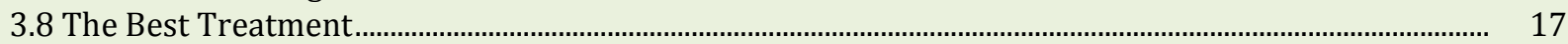

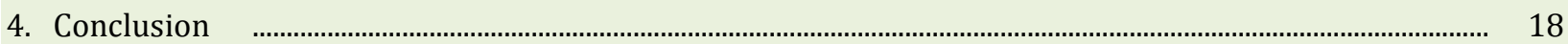

Acknowledgements

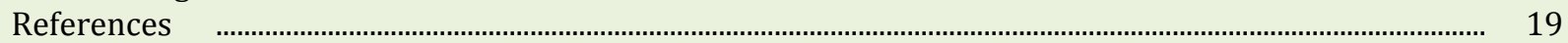

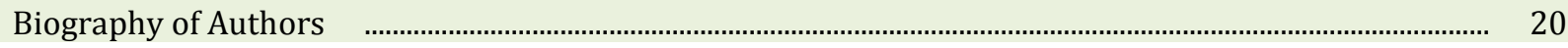

\section{Introduction}

Gelatin is one of the most important raw materials in the word that needs by food industries and nonfood consumption. In Indonesia, gelatin needs on food industries right now become disturbance because of the presentation of consumer confusion about permitted factor. Up to now, gelatin needs are fulfilled by import it from various producer countries but, it permitted is still confusion. The permitted gelatin product is very important to be attended due to the majority of Indonesia population is Muslim. So that, potential exploration of gelatin sources of the animal skin particularly Bali cattle skin need to be a push to increase it positive variation.

Gelatin is one of collagen protein extract results of animal skin for example shank skin broiler. Puspawati et al. (2012) said that extraction collagen protein on shank skin of broiler begins with the process curing with acetic acid at concentration $1.5 \%$ for 3 days resulted in the optimum quality of gelatin via analyzed indicator of FTIR (Fourier Transform Infra Red). But, this method is not yet capable to maximize collagen protein extraction on cattle and goat legs skin. That one of the obstacles to hydrolyze collagen protein on Bali cattle skins particularly in determine the concentration and curing time of optimal acetic acid. The use of acetic acid 1.5\% concentration for 3 days is not capable yet for swelling optimal compare to shank skin of broiler (Miwada et al., 2015). Furthermore, Miwada et al. (2017) said that composition of gelatin amino acid as result of extraction of animal shank skin with acetic acid concentration $1.5 \%$ for 3 days is not capable yet to increase amino acid concentration particularly glycine. It was known that glycine is one of important amino acid in gelatin that causes gelatin has hydrophilic character (Lehninger, 1984) i.e. easy melt in water. The objective of the research was to know the effect of using acetic acid concentration and different curing time to a characteristic of Bali cattle skin gelatin and to determine the best gelatin characteristic. Indicators of the success of the research were $\mathrm{pH}$ values, the yield of gelatin, moisture content, protein, fat, viscosity and gel strength. The success of the research will encourage the maximum increase of the potential of Bali cattle skin into gelatin and as known gelatin is needed with multi-use benefits.

\section{Research Method}

Materials

The main material of the research was a coupon of Bali cattle skin. Others were pH buffer 4.00, pH buffer 7.00, pH buffer 9.00, phenolphthalein (pp), aquades, deionized water, ordinary filter paper, Whatman 42 filter paper. The main equipment of the research was a glassed thermometer, detector, oven, water bath, analytic balance, aluminum pan, plastic pail, blender, stove, and brass.

\section{Method}

The research was designed with use acetic acid concentration treatment factors $(2 ; 4 ; 6$; and $8 \%)$ and curing time $(2 ; 4$ and 6 days). The design of the research was Completely Randomized Design (CRD) factorial patterns ( $4 \times 3$ ), 3 replications in each treatment. Data obtained were analyzed with statistical SPSS version 20. Treatment that showed significantly different $(\mathrm{P}<0.05)$ would be continued to Duncan's Multiple Range test of 5\% level (Steel dan Torrie, 1991).

The research procedure began with make gelatin from Bali cattle skin by using Miwada et al. (2017) methods. The croupon of Bali cattle skin was washed up clean, then it was leaked and curing each by using

Miwada, I., Sumadi, I., Wrasiati, L., \& Sutama, I. (2018). Gelatin characteristics of Bali cattle skin protein extract on acetic acid concentration and different length of curing. International Journal Of Life Sciences (IJLS), 
acetic acid solution concentration 2\% (A1); 4\% (A2); 6\% (A3) and 8\% (A4) and curing time for 2 days (C1); 4 days (C2) and 6 days (C3), then they were washed up clean (up to neutral $\mathrm{pH}$ or negative test to phenolphthalein indicator). The skin that already curing with acid was extracted with ethanol (1:1) for 1 hour to minimize fat. After the extraction was conducted within 1 hour, then continued to wash up again filtering, evaporation of extract solution, and to congeal product of gelatin that was obtained and dried. Gelatin characteristic was tested on $\mathrm{pH}$ value, the yield of gelatin, moisture content, protein fat, viscosity, and gel strength and also a test of treatment effectiveness index according to De Garmo (1984).

\section{Results and Analysis}

\subsection{Value of gelatin $\mathrm{pH}$}

Value of gelatin $\mathrm{pH}$ of collagen protein extraction on Bali cattle skin after curing with acetic acid is significant decrease $(\mathrm{P}<0.05)$ gelatin $\mathrm{pH}$ if the acetic acid concentration is getting high. Even though the longer the curing time of Bali cattle skin in acetic acid solution is not significant effect to gelatin $\mathrm{pH}$. Statistical analyzed result showed that significant interaction $(\mathrm{P}<0.05)$ between acetic acid concentration and curing time of Bali cattle skin. This is due to a hydrolyzed process where utilization of acetic acid resulted in carboxylic acid and amino salt so gelatin would become more acid because the carboxylic acid compound has acid character. This was similar to Alfaro et al. (2014) opinion that gelatin $\mathrm{pH}$ value is affected by the process of extraction that is conducted on skin particularly at curing. Result of $\mathrm{pH}$ value that under $6 \%$ concentration of acetic acid is still matching with GMIA (2015) around up 4.5 - 6.5. So that, the utilization of acetic acid concentration more than $4 \%$ or soaking of bali cattle skin more than 2 days would causes gelatin $\mathrm{pH}$ is low. Although in the process of neutralization after extraction is possible but not maximum yet, gelatin $\mathrm{pH}$ value tends to be very low.

Table 1

Value of Gelatin pH of Bali Cattle Skin Extract with Acetic Acid on Concentration and Length of Different Curing

\begin{tabular}{|c|c|c|c|c|c|}
\hline \multirow{2}{*}{ Curing Time } & \multicolumn{4}{|c|}{ Acetic Acid Concentration } & \multirow{2}{*}{ Average } \\
\hline & $\mathrm{A} 1(2 \%)$ & A2(4\%) & A3(6\%) & $\mathrm{A} 4(8 \%)$ & \\
\hline C1(2 Days) & $4.2^{\mathrm{cd}}$ & $4.0 \mathrm{abc}$ & $4.2^{\mathrm{cd}}$ & $3.8^{\mathrm{a}}$ & $4.05 \pm 0.19$ \\
\hline C2(4 Days) & $4.4 \mathrm{de}$ & $4.1 \mathrm{bc}$ & $4.0 \mathrm{abc}$ & $3.8^{\mathrm{a}}$ & $4.08 \pm 0.26$ \\
\hline C3(6 Days) & $4.5^{\mathrm{e}}$ & $3.9 \mathrm{ab}$ & $3.9 \mathrm{ab}$ & $3.8^{\mathrm{a}}$ & $4.03 \pm 0.30$ \\
\hline Average & $4.37 \pm 0.16^{c}$ & $4 \pm 0.15^{b}$ & $4.03 \pm 0.17 \mathrm{~b}$ & $3.8 \pm 0.09$ a & \\
\hline
\end{tabular}

Note: Different superscript showed that significant different $(\mathrm{P}<0.05)$

\subsection{Yield of gelatin}

The yield of gelatin is an indicator of measurement about treatment effectiveness in order to produce maximum gelatin product. Statistic analyzed on the yield of gelatin showed that increasing of acetic acid concentration and curing could result high $(\mathrm{P}<0.05)$ of the yield of gelatin (Table 2$)$. The capability of acetic acid to open collagen protein band on cattle skin is higher if its concentration is increased, the same result would be obtained if the length of its curing also is increased. Taufik (2011) said that hydrogen band broken down in hydrolyzed gel would be easier for collagen to melt in hot water so the more gelatin would be obtained. Although increasing of acetic acid concentration and length of curing were done in order to break down protein hydrogen band on cattle skin but, the yield of gelatin that is resulted in this treatment is still low about $9.43 \%-12.26 \%$. This mater is suspected due to the opening of collagen structure of cattle skin during swelling by acetic acid solvent and during curing not maximum yet would cause hydrolyzed of collagen protein during extraction. Interaction of acetic acid treatment concentration and length of curing is significant $(\mathrm{P}<0.05)$ affect the yield of gelatin percentage. Acetic acid concentration $8 \%$ with curing for 2 days resulted in high yield of gelatin. 
Table 2

The yield of Gelatin of Bali Cattle Skin Extract with Acetic Acid concentration and Length of Different Curing

\begin{tabular}{|c|c|c|c|c|c|}
\hline \multirow[b]{2}{*}{ Curing Time } & \multicolumn{4}{|c|}{ Acetic Acid concentration } & \multirow{2}{*}{ Average } \\
\hline & $\mathrm{A} 1(2 \%)$ & A2(4\%) & A3(6\%) & A4(8\%) & \\
\hline C1(2 Days) & 9.92 a & $9.46^{a}$ & $12.00^{d}$ & $12.26^{\mathrm{d}}$ & $10.91 \pm 1.32^{\mathrm{b}}$ \\
\hline C2(4 Days) & $9.43^{a}$ & 10.00 ab & $10.68^{c}$ & $9.78^{a}$ & $9.97 \pm 0.53^{\mathrm{a}}$ \\
\hline C3(6 Days) & $10.57^{b c}$ & $10.68^{c}$ & $11.83 \mathrm{~d}$ & $11.91^{\mathrm{d}}$ & $11.25 \pm 0.76^{c}$ \\
\hline Average & $9.97 \pm 0.54^{a}$ & $10.05 \pm 0.57^{\mathrm{a}}$ & $11.50 \pm 0.83^{\mathrm{b}}$ & $11.32 \pm 1.17^{\mathrm{b}}$ & \\
\hline
\end{tabular}

Note: Different superscript showed that significant different $(\mathrm{P}<0.05)$

\subsection{Moisture content of gelatin}

The moisture content of gelatin is an important indicator in evaluation of its quality that would affect performance product, texture, and endurance during preserve (Winarno, 1995). The result of statistic analyzed showed that the moisture content of gelatin is significantly increased $(\mathrm{P}<0.05)$ if the acetic acid concentration is increased as well as it curing time. The interaction between both of the treatments is significant $(\mathrm{P}<0.05)$ affected moisture content of gelatin. This may cause by the capability of acetic acid to open hydrogen band in it collagen protein on cattle skin if its concentration is increased as well as curing time. This affects to it collagen protein structure opened on cattle skin. But it was predicted not automatically weaken hydrogen band with protein in gelatin structure that produce in the dried process it gelatin moisture content is high. Even though, the moisture content of gelatin that was resulted from 12 treatments combination is still much lower than that maximum level of Standard National Indonesia (SNI, 1995) i.e. $16 \%$.

Table 3

Average of Moisture Content of Gelatin of Bali Cattle Skin Extract with Acetic Acid concentration and Length of Different Curing

\begin{tabular}{|c|c|c|c|c|c|}
\hline \multirow{2}{*}{ Curing Time } & \multicolumn{4}{|c|}{ Acetic Acid concentration } & \multirow{2}{*}{ Average } \\
\hline & $\mathrm{A} 1(2 \%)$ & A2(4\%) & A3(6\%) & $\mathrm{A} 4(8 \%)$ & \\
\hline C1(2 Days) & $7.14^{\mathrm{a}}$ & $7.50 \mathrm{bc}$ & $7.63 \mathrm{~cd}$ & $9.09^{f}$ & $7.84 \pm 0.78^{a}$ \\
\hline C2(4 Days) & $7.64 \mathrm{~cd}$ & $7.83^{d}$ & $8.33^{d}$ & $9.65 \mathrm{~g}$ & $8.24 \pm 0.86^{b}$ \\
\hline C3(6 Days) & $8.55 \mathrm{e}$ & $7.35 \mathrm{~b}$ & $7.02^{a}$ & $10.00^{\mathrm{h}}$ & $8.23 \pm 1.23^{\mathrm{b}}$ \\
\hline Average & $7.78 \pm 0.63^{b}$ & $7.56 \pm 0.23^{\mathrm{a}}$ & $7.49 \pm 0.37 \mathrm{a}$ & $9.58 \pm 0.41^{\mathrm{c}}$ & \\
\hline
\end{tabular}

Note: Different superscript showed that significant different $(\mathrm{P}<0.05)$

\subsection{Protein content of gelatin}

The result of statistic analyzed showed that the increase of acetic acid concentration was significant $(\mathrm{P}<0.05)$ decreased protein content of gelatin of Bali cattle skin. The same response also happened on the length of curing. Both of the treatments gave significant interaction $(\mathrm{P}<0.05)$ in decreased protein content. This acetic acid capable to make swelling of cattle skin and that affair more strength happened on Bali cattle skin if curing time and acetic acid concentration is increased. This increase affects the ease of degradation of cattle skin protein during hydrolysis to be gelatin. Kolodziejska et al. (2004) showed that the chemicals used during the process can affect the protein structure formation. The use of acetic acid in Bali cattle skin protein extraction causes polypeptide structure which breaks down into gelatin that marked with a change of it collagen structure (triple helix) as the composition of protein on cattle skin to be a single chain. Wang et al. (2008) said that increased acid concentration during curing caused increase of solubility of collagen protein.

Miwada, I., Sumadi, I., Wrasiati, L., \& Sutama, I. (2018). Gelatin characteristics of Bali cattle skin protein extract on acetic acid concentration and different length of curing. International Journal Of Life Sciences (IJLS), 
Table 4

Average of Protein Content of Gelatin of Bali Cattle Skin Extract with Acetic Acid concentration and Length of Different Curing

\begin{tabular}{|c|c|c|c|c|c|}
\hline \multirow{2}{*}{ Curing Time } & \multicolumn{4}{|c|}{ Acetic Acid concentration } & \multirow{2}{*}{ Average } \\
\hline & A1(2\%) & $\mathrm{A} 2(4 \%)$ & A3(6\%) & A4(8\%) & \\
\hline C1(2 Days) & $96.53 j$ & $95.12 \mathrm{hi}$ & $94.75 \mathrm{gh}$ & $93.64 \mathrm{f}$ & $95.01 \pm 1.11^{c}$ \\
\hline C2(4 Days) & $95.45^{\mathrm{i}}$ & $94.32 \mathrm{~g}$ & $91.26^{\mathrm{d}}$ & $92.12 \mathrm{e}$ & $93.2 \pm 1.83 \mathrm{~b}$ \\
\hline C3(6 Days) & $84.43^{\text {a }}$ & $84.44^{\mathrm{a}}$ & $85.76^{b}$ & $88.13^{c}$ & $85.69 \pm 1.59$ a \\
\hline Average & $92.14 \pm 5.81^{c}$ & $91.29 \pm 5.16^{b}$ & $90.59 \pm 3.93$ & $91.19 \pm 2.45$ & \\
\hline
\end{tabular}

Note: Different superscript showed that significant different $(\mathrm{P}<0.05)$

\subsection{Fat content of gelatin}

Quality of gelatin during preserve would be affected by fat content in gelatin. In the production process, fat in gelatin is expected low as an indicator that gelatin is high quality or if it is preserved would be free of rancidity. The result of statistic analyzed (Table 5) showed that fat gelatin significantly decreased $(\mathrm{P}<0.05)$ if the acetic acid concentration is increased. Additional curing time also tends to significant $(\mathrm{P}<0.05)$ decreased fat on gelatin of Bali cattle skin. Interaction of both treatment factor is also significant $(\mathrm{P}<0.05)$ decreased fat content. In interaction of treatment between an acetic acid (8\%) concentration and curing time for 6 days resulted in the lowest fat content $(\mathrm{P}<0.05)$. This was suspected due to increase of acetic acid concentration in process of curing of cattle skin that causing swelled of skin is increased and in the hydrolysis process particularly at decreasing time with ethanol solution would cause fatter the dissolved and separated formation gelatin helix structure. But generally, fat content of gelatin that produce in all combination of this treatment is still lower compared to that recommended by GMIA (2012) that fat content of gelatin is not more than $5 \%$ of total gelatin weight.

Table 5

Average of Fat Content of Gelatin of Bali Cattle Skin Extract with Acetic Acid concentration and Length of Different Curing

\begin{tabular}{|c|c|c|c|c|c|}
\hline \multirow{2}{*}{ Curing Time } & \multicolumn{4}{|c|}{ Acetic Acid concentration } & \multirow{2}{*}{ Average } \\
\hline & $\mathrm{A} 1(2 \%)$ & A2(4\%) & $\mathrm{A} 3(6 \%)$ & $\mathrm{A} 4(8 \%)$ & \\
\hline C1(2 Days) & $2.49 \mathrm{~g}$ & $2.35^{f}$ & $2.12 \mathrm{e}$ & $2.57 \mathrm{~g}$ & $2.38 \pm 0.2^{c}$ \\
\hline C2(4 Days) & $1.43^{c}$ & 2.11 e & $1.13 \mathrm{~b}$ & $1.10 \mathrm{ab}$ & $1.44 \pm 0.43 b$ \\
\hline C3(6 Days) & $1.19 \mathrm{~b}$ & $1.67^{\mathrm{d}}$ & $1.23^{b}$ & $0.98^{\text {a }}$ & $1.27 \pm 0.27 \mathrm{a}$ \\
\hline Average & $1.7 \pm 0.61 \mathrm{~b}$ & $2.04 \pm 0.31^{c}$ & $1.49 \pm 0.47 \mathrm{a}$ & $1.55 \pm 0.77$ & \\
\hline
\end{tabular}

Note: Different superscript showed that significant different $(\mathrm{P}<0.05)$

\subsection{Gelatin viscosity}

Gelatin viscosity as an indicator of gelatin physical test quality. Collagen protein extract of Bali cattle skin to be gelatin is effected by time and length curing with acetic acid. Statistic analyzed result showed that increase of acetic acid concentration is significant $(\mathrm{P}<0.05)$ decreased gelatin viscosity (Table 7). The increase of curing time is also increased affected gelatin viscosity $(\mathrm{P}<0.05)$. Interaction of both treatments is significantly decreased gelatin viscosity $(\mathrm{P}<0.05)$. Skin of Bali cattle during the process of acetic acid curing showed physic changes i.e. swelling, so easier in warming extraction with water (hydrolysis). The increased of acetic acid would easier to cut down the covalent band in tropocollagen structure (Go'mez-Guille'n et al. (2005), as the structure of collagen on Bali cattle skin. But, the high acetic acid concentration would affect on decreased viscosity. Even though, because of acetic acid is a weak acid so, it would not denaturation skin collagen of Bali cattle totally in the process to be gelatin. Gelatin viscosity as result of curing with a concentration of acetic acid 2\% - 8\% and curing time $2-6$ days still match with viscosity value recommended in the SNI (1995) i.e. between $2.0-7.5 \mathrm{cP}$ 
Table 7

Average of Viscosity of Gelatin of Bali Cattle Skin Extract with Acetic Acid concentration and Length of Different Curing

\begin{tabular}{|c|c|c|c|c|c|}
\hline \multirow{2}{*}{ Waktu Curing } & \multicolumn{4}{|c|}{ Acetic Acid concentration } & \multirow{2}{*}{ Average } \\
\hline & $\mathrm{A} 1(2 \%)$ & A2(4\%) & A3(6\%) & A4(8\%) & \\
\hline C1(2 Days) & $7.71^{\mathrm{h}}$ & $7.52 \mathrm{~g}$ & $7.25^{\mathrm{f}}$ & $6.45 \mathrm{~cd}$ & $7.23 \pm 0.5^{c}$ \\
\hline C2(4 Days) & $7.32^{\mathrm{f}}$ & 6.89 e & $6.56^{d}$ & $6.43^{c}$ & $6.80 \pm 0.37 b$ \\
\hline C3(6 Days) & $7.25^{\mathrm{f}}$ & $6.45 \mathrm{~cd}$ & $5.67^{b}$ & $5.35^{\mathrm{a}}$ & $6.18 \pm 0.77 \mathrm{a}$ \\
\hline Average & $7.43 \pm 0.22 \mathrm{~d}$ & $6.95 \pm 0.47 \mathrm{c}$ & $6.49 \pm 0.69 \mathrm{~b}$ & $6.08 \pm 0.55 \mathrm{a}$ & \\
\hline
\end{tabular}

Note: Different superscript showed that significant different $(\mathrm{P}<0.05)$

\subsection{Gelatin gel strength}

The result of statistic test showed that increased utilization of acetic acid concentration was decreased gelatin gel strength significantly $(\mathrm{P}<0.05)$. On table 8 . Showed that interaction of both factors treatments is significantly $(\mathrm{P}<0.05)$ affect decreased of gelatin gel strength. The higher the acetic acid concentration and at the same curing time increase this would result in weakness of gel strength. Gelatin gel strength is affected by long of an amino acid chain and it could be reached if hydrolysis process happens at the perfect time on polypeptide chain. On Bali cattle skin hydrolysis that already swelling, it collagen skin structure broken down on the cross band and hydrogen band that function as a stabilizer of collagen structure. Go'mezGuille'n et al. (2005) said that the broken would stabilized triple helix. Furthermore, he said that this triple helix three-dimensional structure can expand because it absorbs water osmosis so that it becomes a semisolid material that can maintain its shape and elasticity when applied pressure.

Table 8

Average Gel Strength (Blom) of Gelatin of Bali Cattle Skin Extract with Acetic Acid Concentration and Length of Different Curing

\begin{tabular}{|c|c|c|c|c|c|}
\hline \multirow{2}{*}{ Curing Time } & \multicolumn{4}{|c|}{ Acetic Acid Concentration } & \multirow{2}{*}{ Average } \\
\hline & $\mathrm{A} 1(2 \%)$ & A2(4\%) & A3(6\%) & A4(8\%) & \\
\hline C1(2 Days) & $12.85 \mathrm{~g}$ & $12.45^{\mathrm{e}}$ & $12.18^{\mathrm{d}}$ & $11.49^{b}$ & $12.24 \pm 0.52 \mathrm{~b}$ \\
\hline C2(4 Days) & $12.76 \mathrm{fg}$ & 12.54 ef & $11.89 \mathrm{c}$ & $12.12^{\mathrm{cd}}$ & $12.33 \pm 0.38 \mathrm{~b}$ \\
\hline C3(6 Days) & $12.96 \mathrm{~g}$ & $12.59 \mathrm{e}$ & 11.23 a & $11.15^{\mathrm{a}}$ & $11.98 \pm 0.85^{a}$ \\
\hline Average & $12.86 \pm 0.16^{\mathrm{d}}$ & $12.53 \pm 0.17$ & $11.77 \pm 0.44 \mathrm{~b}$ & $11.59 \pm 0.43 \mathrm{a}$ & \\
\hline
\end{tabular}

Note: Different superscript showed that significant different $(\mathrm{P}<0.05)$

\subsection{The best treatment}

Determination of effectiveness of treatments combination between the concentration of acetic acid and it curing time was decided according to a method of De Garmo (1984). The result of effective index of treatments combination was presented in Table 9. Base on that test, the best treatment was selected base the highest of treatment effectiveness i.e. a combination of treatment A4C3 (with a value of 1.04). The best treatment combination in producing gelatin of Bali cattle skin extract was the utilization of acetic acid on concentration $8 \%$ with the length of curing time for 6 days.

Table 9

Gelatin Effectiveness Test of Bali Cattle Skin Extract with Acetic Acid Concentration and Length of Different Curing

\begin{tabular}{ccccccccccccc}
\hline \multirow{2}{*}{ Variable } & \multicolumn{10}{c}{ Treatment } \\
\cline { 2 - 11 } & A1C1 & A1C2 & A1C3 & A2C1 & A2C2 & A2C3 & A3C1 & A3C2 & A3C3 & A4C1 & A4C2 & A4C3 \\
\hline $\begin{array}{c}\text { Effectiveness } \\
\text { value }\end{array}$ & 0.66 & 0.64 & 0.48 & 0.57 & 0.55 & 0.44 & 0.76 & 0.61 & 0.56 & 0.55 & 0.43 & 1.04 \\
\hline
\end{tabular}

Miwada, I., Sumadi, I., Wrasiati, L., \& Sutama, I. (2018). Gelatin characteristics of Bali cattle skin protein extract on acetic acid concentration and different length of curing. International Journal Of Life Sciences (IJLS), 


\section{Conclusion}

Acetic acid concentration and curing duration produce gelatin with significant interaction differences. The results of the analysis produced the best gelatin that met the indicator variables from different treatment combinations. The best combination was A1C3 with pH (4.5) and gelatin gel strength (12.96 blom); A4C1 produced gelatin yield (12.26\%). Combination of A3C3 produced moisture content (7.02\%), while A1C1 produced gelatin protein $(96.53 \%)$ and viscosity $(7.71 \mathrm{cP})$. Combination A4C3 produced gelatin fat $(0.98 \%)$ but, all combination were not significantly affected to gelatin ash. The result of effectiveness index was found that the best treatment combination on the concentration of acetic acid $8 \%$ and curing time 6 days (A4C3) produced gelatin product from Bali cattle skin. Quality indicator were gelatin yield (11.91\%); moisture content (10\%); protein (88.13\%); fat (0.98\%) and viscosity (5.35 cP).

\section{Conflict of interest statement and funding sources}

The authors declared that they have no competing interest. The study was financed by personal funding.

\section{Statement of authorship}

The authors have a responsibility for the conception and design of the study. The authors have approved the final article.

\section{Acknowledgments}

On this opportunity, the authors would like to thank the Rector of Udayana University and the dean of the faculty of animal science Udayana University for their permits and facilities so that the research can be done well. 


\section{References}

1. Alfaro, A. T., Biluca, F. C., Marquetti, C., Tonial, I. B., \& de Souza, N. E. (2014). African catfish (Clarias gariepinus) skin gelatin: Extraction optimization and physical-chemical properties. Food research international, 65, 416-422.

View in (Google Scholar)

2. De Garmo, E. P., Sullevan, W. E., \& Canana, C. R. (1984). Engineering Economy 7th. Ed. Macmilland Publ. Co., New York.

View in (Google Scholar)

3. Gómez-Guillén, M. C., Giménez, B., \& Montero, P. (2005). Extraction of gelatin from fish skins by high pressure treatment. Food hydrocolloids, 19(5), 923-928.

View in (Google Scholar)

4. Hasdar, M., \& Rahmawati, Y. D. (2016). Nilai pH, titik leleh dan viskositas pada gelatin kulit domba asal brebes yang dikatalis berbagai konsentrasi NaOH. Parapemikir: Jurnal Ilmiah Farmasi, 5(2).

View in (Google Scholar)

5. Kolodziejska, I., Kaczorowski, K., Piotrowska, B., \& Sadowska, M. (2004). Modification of the properties of gelatin from skins of Baltic cod (Gadus morhua) with transglutaminase. Food Chemistry, 86(2), 203-209.

View in (Google Scholar)

6. Lehninger, A. L. (1982). Principles of biochemistry (Dasar-dasar biokimia, Jilid 2, diterjemahkan oleh M. Thenawijaya. 1992). Penerbit Erlangga. Jakarta.

View in (Google Scholar)

7. Miwada, I. N., Simpen, I. N., Hartawan, M., Puger, A. W., \& Sriyani, N. L. (2015). Karakteristik gelatin dari kulit kaki ternak dan potensinya sebagai edible film. Majalah Ilmiah Peternakan, 18(3).

View in (Google Scholar)

8. Miwada, IN.S., IK. Sukada, W.S. Yupardhi dan S.A. Lindawati. (2017). Amino Acid Profile on Shank Skin of Livestock and Antibacterial Potential Study. International Research Journal of Engineering, IT \& Scientific Research, 3(4) : 99-104.

View in (Google)

9. Nasional, B. S. (1995). SNI 06-3735-1995. Mutu dan Cara Uji Gelatin, Jakarta.

View in (Google Scholar)

10. Omer, A. M. (2017). Identifying, Developing, and Moving Sustainable Communities through Application of Bioenergy for Energy or Materials: Future Perspective through Energy Efficiency. International Journal of Life Sciences (IJLS), 1(1), 9-39.

View in (Google Scholar)

11.Puspawati, N. M., Simpen, I. N., \& Miwada, S. (2012). Isolasi gelatin dari kulit kaki ayam broiler dan karakterisasi gugus fungsinya dengan spektrofotometeri FTIR. Jurnal Kimia, 6(1), 87-79.

View in (Google Scholar)

12. Saxena, A. (2017). The Impact of Nutrition on the Overall Quality of Life Adolescent Girls are Living Across the City of Kota. International Journal of Life Sciences (IJLS), 1(1), 40-48.

View in (Google Scholar)

Miwada, I., Sumadi, I., Wrasiati, L., \& Sutama, I. (2018). Gelatin characteristics of Bali cattle skin protein extract on acetic acid concentration and different length of curing. International Journal Of Life Sciences (IJLS), 2(2), 12-21. doi:10.29332/ijls.v2n2.119 
13. Sriyani, N. L. P., Siti, W., Suarta, G., Partama, I. B. G., Ariana, N. T., \& Yupardhi, W. S. (2018). Responses of Corncob as Replacement of Elephant Grass on Performance and Carcass Profile of Bali Cattle. International Journal of Life Sciences (IJLS), 2(1), 42-49.

View in (Google Scholar)

14. Steel, R. GD and TORRIE, JH (1980). Principle and Procedure of Statistics A Biomedical Approach. View in (Google Scholar)

15. Taufik, M., \& Pt, S. (2011). Potensi Kulit Kaki Broiler Sebagai Bahan Dasar Gelatin Dan Edible Film (Doctoral dissertation, Universitas Gadjah Mada).

View in (Google Scholar)

16. Wang, L., Auty, M. A., Rau, A., Kerry, J. F., \& Kerry, J. P. (2009). Effect of pH and addition of corn oil on the properties of gelatin-based biopolymer films. Journal of food engineering, 90(1), 11-19.

View in (Google Scholar)

17. Winanrno, F. G. (1992). Kimia pangan dan gizi.

View in (Google Scholar) 


\section{Biography of Authors}

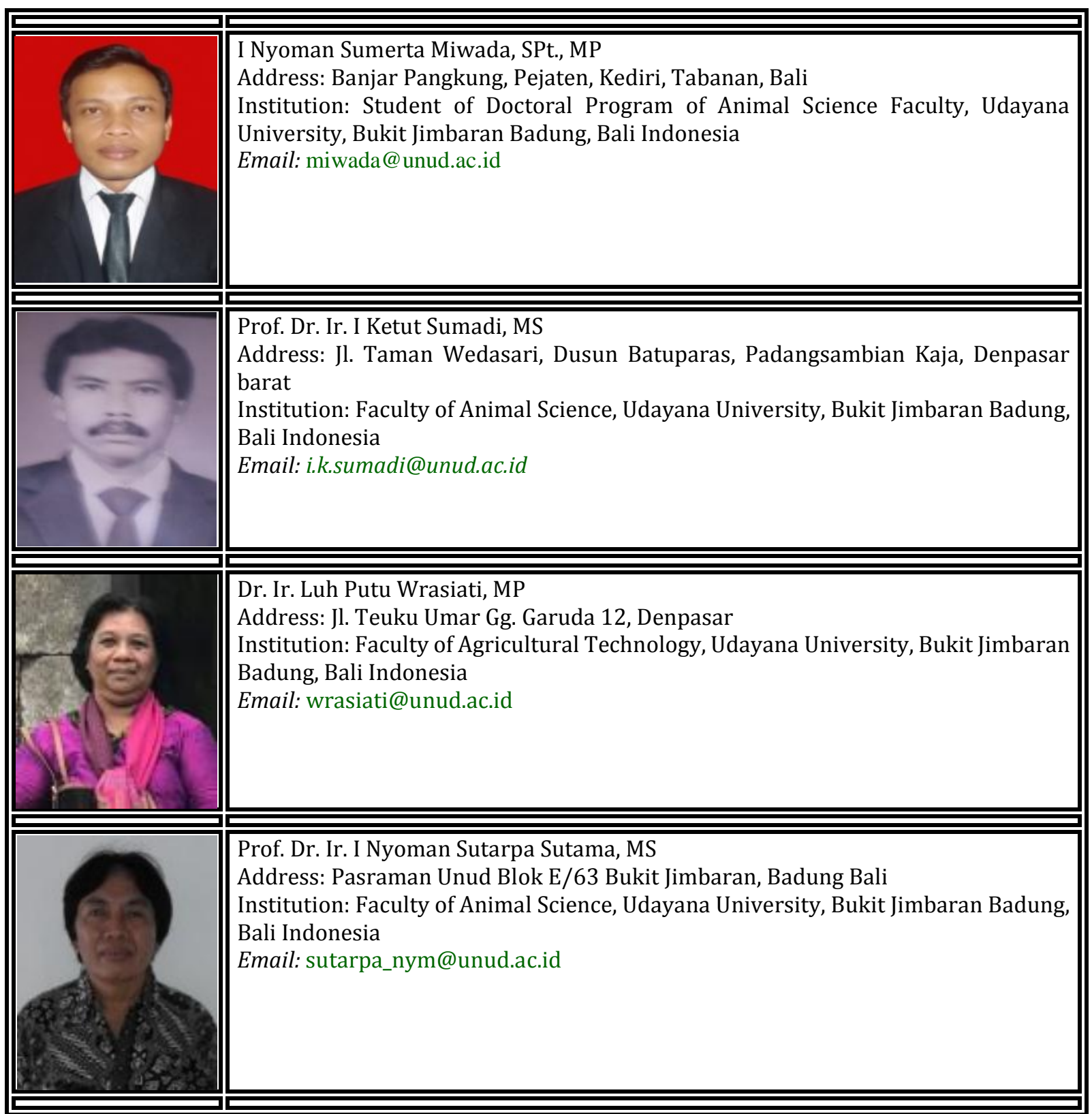

Miwada, I., Sumadi, I., Wrasiati, L., \& Sutama, I. (2018). Gelatin characteristics of Bali cattle skin protein extract on acetic acid concentration and different length of curing. International Journal Of Life Sciences (IJLS), 2(2), 12-21. doi:10.29332/ijls.v2n2.119 